\section{Conservation for the 21st Century}

Edited by David Western and Mary Pearl

Oxford University Press, Oxford and New York, 1989, 365 pp., HB $£ 28.00$

What a splendid book to start the 1990s! Being the proceedings of a conference arranged by the New York Zoological Society, it largely examines the gross depletion of wildlife and its habitats, both present and prospective. Paper after illuminating paper demonstrates that the mass extinction under way is, for the first time in the history of mass extinctions, the doings of a single species; and that ironically the same species is the only one ever to be able to safeguard the other species.

It is this latter perspective that informs much of the book. No catalogue of gloom and doom, it demonstrates that policy initiatives and management measures are available to do a far better job of stemming wildlands destruction. As a casebook study of what we can do if only we mobilize the will, it is uniquely optimistic. For this we must primarily thank the instigator of the conference, David Western, one of the most imaginative as well as scholarly of all ecologists-and perhaps the most positive-spirited of them all: 'If humanity is the sole threat to wildlife, it is also its only hope.' Who else would think to ask whether we should concentrate not only on saving as many species as we can, but also watch out for an even more important imperative, safeguarding the integrity of nature.

With cogently argued papers by such luminaries as $\mathrm{Ed}$ Wilson, Storrs Olson, Sam McNaughton, Brian Walker, Alvaro Ugalde, Jeff McNeely and Bill Conway among a host of others, this is a book that I shall return to often-for information, insight and inspiration. Norman Myers.

\section{The Global Environmental Movement}

John McCormick

Belhaven Press, London, 1989, 259pp., HB $£ 27.50$

This 'stock-taking' book reviews the environmental movement from 1945 to the mid-1980s, viewing it as an economic, social and political phenomenon of global scope. It traces the early concerns of preservationists, the mass movements of the late $1960 \mathrm{~s}$ and early 1970s, and the more pragmatic responses from the late 1970 s onwards. Thus, it covers such landmark events as Silent Spring, Minemata Bay, the Stockholm Conference, the arrival of UNEP, Chernobyl, the rising environmental interest of developing countries, and the Brundtland Commission.

An interesting history of the phenomenon, it is sound on information and documentation, but rather light on analysis and evaluation. For instance, while it does a good job on describing the interrelationships between environment and development in both the North and South, it does not go as deeply and systematically as this reviewer would like into the dynamic interplay between the two fields. How are ecological-economic tradeoffs to be tackled in programmatic fashion? How are policy makers to deal with the many uncertainties that beset the debate? An arch-example, the greenhouse effect, receives only short shrift. One of the most intractable issues, tropical deforestation is mentioned only in passing. Nor is there much sustained treatment of the chal- lenge of global resources and environmental interdependen$c y$, or of the environmental impacts of international trade and the debt problem.

These shortcomings apart, the book can be solidly recommended as a background account of a phenomenon that will surely dominate the next 40 years.

Norman Myers.

\section{Public Policies and the Misuse of Forest Resources}

Edited by Robert Repetto and Malcolm Gillis

Cambridge University Press, Cambridge, 1988, 432 pp., PB $£ 19.50$

The degradation and deforestation of forest lands results from land-use activities controlled by a variety of public policies. Forests are cut for agriculture, silviculture and planned settlement schemes. Large areas are degraded by timber extraction. All these processes are under the control of local or central governments. In many countries such bureaucracies have discouraged conservation of the forest resources and aggravated the pressures on forests from growing human populations; this compilation provides details of the problems.

An Overview explains the cycle of tropical deforestation and impoverishment in broad terms, leading into seven detailed and heavily referenced chapters dealing with Indonesia, Malaysia, Philippines, China, the Brazilian Amazon, West Africa and finally the United States of America.

In the Conclusion, the editors emphasize that changes in policy can substantially reduce resource wastage, seen as the fundamental problem in the 